\title{
KONTRIBUSI USAHATANI KELAPA SAWIT DALAM MENINGKATKAN KESEJAHTERAAN RUMAHTANGGA PETANI DI KABUPATEN ACEH UTARA
}

\section{THE CONTRIBUTION OF OIL PALM FARMING IN IMPROVING FARMER HOUSEHOLD WELFARE IN ACEH UTARA DISTRICT}

\author{
Jamilah**1, Mawardati $^{1}$, Ghazali Syamni ${ }^{2}$ \\ ${ }^{1}$ Fakultas Pertanian Universitas Malikussaleh - Lhokseumawe - Aceh \\ ${ }^{2}$ Fakultas Ekonomi Universitas Malikussaleh - Lhokseumawe - Aceh \\ *E-mail: jamilah@unimal.ac.id
}

(Diterima 24-12-2021; Disetujui 22-01-2022)

\begin{abstract}
ABSTRAK
Kelapa sawit sebagai komoditas unggulan ekspor di Propinsi Aceh dalam pengembangannya menghadapi kendala baik pada tingkat budidaya maupun pasca panen dan pemasaran yang akan menentukan pendapatan dan kesejahteraan petani. Penelitian bertujuan untuk menganalisis kontribusi usahatani kelapa sawit dalam meningkatkan kesejahteraan petani. Metode penelitian menggunakan metode survei terhadap petani kelapa sawit rakyat. Hasil penelitian menunjukkan bahwa usahatani kelapa sawit dikategorikan cukup berkontribusi dalam meningkatkan kesejahteraan rumahtangga petani. Untuk mencapai kategori hidup layak, maka petani harus memiliki lahan seluas 2,08 hektar atau harga jual TBS minimal senilai Rp1.553,40 per $\mathrm{kg}$. Peningkatan produktivitas kelapa sawit dan pengembangan industri sawit hendaknya menjadi skala prioritas dalam mengantisipasi fluktuasi harga CPO yang berimplikasi kepada fluktuasi harga jual TBS di tingkat petani.
\end{abstract}

Kata kunci: kontribusi, kelapa sawit, kesejahteraan, petani

\section{ABSTRACT}

Oil palm as a leading export commodity in Aceh Province in its development faces obstacles both at the cultivation and post-harvest and marketing levels which will determine the income and welfare of farmers. This study aims to analyze the contribution of oil palm farming in improving farmer welfare. The research method used a survey method of smallholder oil palm farmers. The results showed that oil palm farming was categorized as contributing enough to improving the welfare of farmer households. To achieve a decent living category, farmers must own 2.08 hectares of land or a minimum selling price of Rp1,553.40 per $\mathrm{kg}$. Increasing productivity of oil palm should be a priority scale in anticipating fluctuations in CPO prices which have implications for fluctuations in the selling price of TBS at the farm level.

Keywords: contribution, oil palm, welfare, farmers

\section{PENDAHULUAN}

Kelapa sawit merupakan komoditas ekspor unggulan dan sebagai sumber devisa negara, menyerap banyak tenaga kerja, dan berkontribusi terhadap Produk Nasional Bruto (PDB), dan menumbuhkan pusat-pusat pertumbuhan ekonomi pedesaan serta menembus pasar global secara berkelanjutan (FAO, 2013; Wildayana, 2014; Lee et al, 2011). Di Propinsi Aceh, kelapa sawit merupakan salah satu komoditas unggulan utama, 
didukung oleh kondisi iklim dan topografi yang cocok untuk pertumbuhan kelapa sawit serta memiliki lahan yang luas. Data Badan Pusat Statistik menunjukkan adanya tren peningkatan luas areal dan produksi kelapa sawit setiap tahunnya. Pada tahun 2017 lahan kelapa sawit seluas 234.479 ha dan produksi sebanyak 437.292 ton meningkat menjadi 237.769 hektar dengan produksi sebanyak 440.087 ton pada tahun 2018 yang dikembangkan di 12 kabupaten di Propinsi Aceh. Jumlah petani sawit sebanyak 127.155 orang dan jumlah tenaga kerja di perkebunan sawit, sebanyak 117.654 orang (Badan Pusat Statistik Aceh, 2019). Kelapa sawit merupakan bahan baku pembuatan Crude Palm Oil (CPO) dan produk olahan lainnya seperti margarin, bahan bakar nabati (BBN), sabun, detergen dan surfaktan, kosmetik, obat-obatan serta beraneka ragam produk rumah tangga (Ardana dan Kariyasa, 2016). Propinsi Aceh mampu menghasilkan 1,9 juta ton CPO dari 45 perusahaan CPO.

Kabupaten Aceh Utara merupakan daerah sentra produksi kelapa sawit dengan lahan seluas 21.145 ha dan produksi sebanyak 48.812 ton. Rata-rata produktivitas kelapa sawit sebesar 3.927 kg per hektar lebih tinggi dibanding kabupaten lainnya. Jumlah petani kelapa sawit sebanyak 10.794 orang dengan penyerapan tenaga kerja sebanyak 9.093 orang (Badan Pusat Statistik Kabupaten Aceh Utara, 2019).

Peningkatan luas areal dan produksi kelapa sawit tidak diikuti dengan peningkatan pendapatan dan kesejahteraan petani. Adanya fluktuasi harga TBS di tingkat petani akibat adanya penurunan permintaan CPO dari negara mitra dagang yang berimplikasi kepada penurunan harga jual CPO dan berimplikasi langsung kepada penurunan harga TBS di tingkat Petani. Pada rentang tahun 2018-2020 terjadi krisis ekonomi akibat perang dagang China dengan Amerika Serikat dan dilanjutkan dengan krisis akibat pandemi Covid-19 yang berdampak terjadinya penurunan permintaan $\mathrm{CPO}$ dan produk turunannya dari beberapa negara mitra dagang utama seperti India, China, Timur Tengah, dan negara-negara Eropa (Jamilah, et al, 2016; Jamilah et al, 2020, Mawardati, et al, 2021).

Dampak dari penurunan harga di tingkat petani adalah peremajaan perkebunan kelapa sawit yang dapat tersendat akibat ketiadaan modal (Gumilar, 2018). Budidaya dan pengelolaan pasca panen sangat 


\section{KONTRIBUSI USAHATANI KELAPA SAWIT DALAM MENINGKATKAN KESEJAHTERAAN RUMAHTANGGA PETANI DI KABUPATEN ACEH UTARA \\ Jamilah, Mawardati, Ghazali Syamni}

mempengaruhi harga jual Tandan Buah Segar (TBS) di tingkat petani. Banyak petani yang mengeluh akibat adanya penurunan pendapatan.

Banyak faktor yang menentukan harga jual kelapa sawit di tingkat petani diantaranya kualitas TBS, teknik pasca panen, dan pola pemasaran TBS. Sebagian besar petani menggantungkan modal usahatani dari pedagang pengumpul dengan konsekuensi menjual TBS dengan harga jual yang ditentukan oleh pedagang. Adanya perbedaan akses input, akses finansial dan akses pasar menyebabkan keterbatasan petani dalam mengelola kebun sawitnya sehingga pendapatan dan produktivitas petani swadaya cenderung lebih rendah apabila dibandingkan dengan petani plasma (Lestari et al, 2015; Rist et al, 2010; Waarts dan Zwart, 2013).

Sejumlah lahan usahatani kelapa sawit rakyat sudah memasuki masa replanting. Dalam hal ini, umumnya petani melakukan replanting tanaman secara sisipan. Guna mengatasi keterbatasan modal usahatani, sejak tahun 2019 hingga sekarang, pemerintah daerah melalui instansi terkait telah memberikan bantuan dana replanting sebesar Rp25 juta per hektar lahan petani rakyat. Berbagai upaya dilakukan pemerintah untuk membantu meningkatkan pendapatan petani kelapa sawit, namun fakta di lapangan menunjukkan bahwa sistim budidaya, teknik pasca panen, dan pemasaran tetap menjadi permasalahan petani yang berimplikasi terhadap penurunan kualitas dan harga jual TBS sehingga mempengaruhi pendapatan dan kesejahteraan rumah tangga petani. Tingkatan harga TBS yang dapat ditolerir di tingkat petani guna meningkatkan pendapatan petani kelapa sawit perlu dikaji mendalam sehingga dapat memotivasi petani dalam mengembangkan usahatani kelapa sawit.

\section{METODE PENELITIAN}

Petani sampel berjumlah 160 orang yang diambil secara stratified proporsional simple random sampling. Analisis data menggunakan metode deskriptif kuantitatif meliputi analisis struktur biaya dan pendapatan petani kelapa sawit serta analisis kesejahteraan rumah tangga petani. Pendapatan diperoleh dengan menghitung selisih antara total penerimaan dari hasil usaha dengan total biaya produksi yang dikeluarkan petani selama satu tahun (Hastuti, et al, 2008). Pendapatan petani kelapa sawit dihitung dengan menggunakan rumus : 


$$
\begin{aligned}
& \mathrm{P}=\mathrm{TR}-\mathrm{TC} \\
& \mathrm{P}=\text { pendapatan petani kelapa sawit } \\
& \text { (Rp/ha/tahun) } \\
& \mathrm{TR}=\text { total penerimaan dari usahatani } \\
& \text { kelapa sawit (Rp/ha/tahun) } \\
& \mathrm{TC}=\text { total biaya usahatani kelapa } \\
& \text { sawit ( } \mathrm{Rp} / \mathrm{ha} / \text { tahun) }
\end{aligned}
$$$$
\mathrm{TR}=\mathrm{P}_{\mathrm{Q}} \times \mathrm{Q}
$$$$
\mathrm{P}_{\mathrm{Q}}=\text { Harga jual Tanda Buah Segar }
$$$$
\text { (TBS) }(\mathrm{Rp} / \mathrm{kg})
$$$$
\mathrm{Q}=\text { Jumlah produksi TBS }(\mathrm{kg} / \mathrm{ha})
$$$$
\mathrm{TC}=\mathrm{Px} \cdot \mathrm{X}
$$$$
\mathrm{P}_{\mathrm{x}}=\text { Harga beli input usahatani }
$$$$
\text { (Rp/satuan/ha) }
$$$$
\mathrm{Q}=\text { Jumlah input }(\mathrm{Rp} / \mathrm{satuan} / \mathrm{ha})
$$$$
\mathrm{TC}=\mathrm{TFC}+\mathrm{TVC}
$$$$
\mathrm{TFC}=\text { Total biaya tetap }
$$$$
\text { (Rp/ha/tahun) }
$$$$
\text { TVC }=\text { Total biaya variabel }
$$$$
\text { (Rp/ha/tahun) }
$$

Pengukuran tingkat kesejahteraan dapat dilakukan berdasarkan pengeluaran rumah tangga per kapita per tahun kemudian dibagi dengan harga beras per kilogram. Hasil penelitian dapat digunakan untuk membuktikan apakah usahatani mampu meningkatkan kesejahteraan rumahtangga petani Menurut Sayogyo (1997), peringkat kemiskinan didasarkan pada besarnya pengeluaran per kapita per tahun yang diukur dengan setara harga beras setempat dengan kriteria:

a. Hidup Layak apabila pengeluaran/ kapita/tahun lebih tinggi dari $960 \mathrm{~kg}$ setara nilai beras/tahun.

b. Cukup apabila pengeluaran/kapita/ tahun antara 481-960 kg setara nilai beras/tahun.

c. Nyaris Miskin apabila pengeluaran/ kapita/tahun antara 321-480 kg setara nilai beras/tahun.

d. Miskin apabila pengeluaran/kapita/ tahun lebih rendah dari nilai tukar 320 $\mathrm{kg}$ beras.

e. Miskin Sekali apabila pengeluaran/ kapita/tahun lebih rendah dari nilai tukar $240 \mathrm{~kg}$ beras.

f. Paling Miskin apabila pengeluaran/ kapita/tahun lebih rendah dari nilai tukar $180 \mathrm{~kg}$.

\section{HASIL DAN PEMBAHASAN}

\section{Analisis Biaya Usahatani Kelapa Sawit}

Biaya usahatani kelapa sawit meliputi biaya tetap dan biaya variabel. Biaya tetap adalah biaya yang dikeluarkan besarnya tidak tergantung pada jumlah produksi yang dihasilkan. Biaya ini berupa lahan dan peralatan usahatani. Pengeluaran biaya variabel 


\section{KONTRIBUSI USAHATANI KELAPA SAWIT DALAM MENINGKATKAN KESEJAHTERAAN RUMAHTANGGA PETANI DI KABUPATEN ACEH UTARA \\ Jamilah, Mawardati, Ghazali Syamni}

dipengaruhi oleh banyaknya produksi, meliputi biaya benih, pupuk, tenaga kerja, dan pestisida. Rata-rata biaya yang dikeluarkan dalam usahatani kelapa sawit adalah Rp4.322.000 per hektar per tahun.

Adanya petani yang memiliki ketergantungan modal usahatani dari pedagang (Ellyta, et al, 2020; Jamilah, 2010; Jamilah, 2014). Petani mendapatkan bantuan pinjaman biaya usahatani dan biaya untuk memenuhi kebutuhan rumahtangga dengan kesepakatan hasil panen (TBS) harus dijual kepada pedagang tersebut. Pada kondisi ini petani tidak memiliki peluang memilih saluran pemasaran TBS dan mendapatkan harga jual yang tinggi. Untuk itu, pemerintah melalui instansi terkait telah memberikan beberapa bantuan permodalan usahatani seperti bantuan bibit, pupuk, atau replanting (sebesar Rp 25 juta per hektar per petani). Sebagian besar usahatani rakyat di lokasi penelitian telah memasuki tahap replanting.

Penggunaan tengaa kerja sebanyak 27,78 HOK dan umumnya tenaga kerja berasal dari dalam keluarga dan hanya sebagian kecil dari tenaga luar keluarga dengan tingkat upah rata-rata Rp100.000/HOK.

\section{Produksi dan Penerimaan Usahatani}

Usahatani kelapa sawit dilakukan pada lahan rata-rata seluas 2,5 hektar dengan rata-rata produksi sebanyak 9,27 ton per hektar per tahun. Produktivitas tersebut jauh lebih rendah dibandingkan dengan tingkat produktivitas normal. Pada keadaan yang optimum, produksi TBS dapat mencapai 20-25 ton/ha/tahun atau sekitar 5-6 ton minyak sawit/ha/tahun. Produksi tanaman kelapa sawit dengan menggunakan bibit dari kultur jaringan dapat diperoleh TBS sebanyak 32-40 ton/ha/tahun atau setara 7-9 ton/ha/tahun minyak sawit.

Harga jual TBS di tingkat petani ditentukan oleh kualitas TBS, jarak lokasi pemanenan dengan lokasi penampungan (jalan kebun), jarak lokasi kebun kelapa sawit dengan pabrik kelapa sawit (PKS), dan saluran pemasaran TBS yang dipilih petani. Rata-rata harga jual TBS petani adalah Rp748 per kilogram. Rata-rata jarak lokasi kebun kelapa sawit dengan PKS adalah 37,18 km. Semakin jauh dari lokasi PKS, maka semakin besar biaya pengangkutan dan membutuhkan waktu yang cukup lama untuk pengangkutan sehingga mempengaruhi kualitas TBS dan menentukan harga jual TBS. 
Jumlah produksi CPO di Propinsi Aceh rata-rata sebanyak 2 ton/ha/tahun dari 45 industri CPO (PKS), sedangkan rata-rata nasional sekitar 3,5 ton/ha/tahun yang tersebar di 12 kabupaten yaitu Kabupaten Aceh Tamiang, Aceh Timur, Aceh Utara, Bireuen, Pidie Jaya, Aceh Jaya, Aceh Barat, Nagan Raya, Aceh Barat Daya, Aceh Selatan, Subulussalam, dan Singkil. Rata-rata produksi CPO sebanyak 800 ribu ton per tahun, padahal Propinsi Aceh berpotensi untuk menghasilkan CPO sebesar 1,2 juta ton per tahun.

\section{Kendala pengembangan Usahatani kelapa sawit rakyat}

Adanya beberapa kendala yang dihadapi petani dalam usahatani kelapa sawit sehingga mempengaruhi produksi kelapa sawit dan menentukan pendapatan petani, antara lain:

a. Keterbatasan modal dan sulitnya akses modal perbankan, menyebabkan petani tingkat penerapan memiliki ketergantungan terhadap pedagang dalam memasarkan hasil panen.

b. Adanya kesenjangan produktivitas usahatani akibat rendahya akibat rendahnya tingkat penerapan teknologi terutama teknologi budidaya. c. Tingkat kematangan panen TBS tidak merata karena adanya kecenderungan petani mempercepat proses pemanenan akibat desakan kebutuhan rumahtangga petani.

d. Jarak lokasi kebun yang cukup jauh dari tempat pemungutan hasil dan lokasi PKS serta belum adanya sarana pengangkutan yang memadai.

e. Sebagian besar tanaman sudah berumur lebih dari 20 tahun sehingga produksi semakin menurun.

f. Tidak adanya sarana transportasi yang memadai pada daerah sentra produksi sehingga ada kecenderungan petani menjual kepada pedagang di lokasi pemanenan.

g. Adanya petani yang tidak menggunakan bibit bersertifikat sehingga produktivitas rendah.

h. Masih terbatasnya industri CPO (PKS) dan belum adanya industri hilir produk lainnya. Pada lahan kelapa sawit seluas 237.769 hektar hanya memiliki 45 PKS di Propinsi Aceh sehingga 1 (satu) PKS untuk mengolah 48.980,36 ton TBS dari 5.283,75 hektar lahan kelapa sawit. 


\section{KONTRIBUSI USAHATANI KELAPA SAWIT DALAM MENINGKATKAN KESEJAHTERAAN \\ RUMAHTANGGA PETANI DI KABUPATEN ACEH UTARA \\ Jamilah, Mawardati, Ghazali Syamni}

Pendapatan petani kelapa sawit dan kontribusinya terhadap kesejahteraan rumahtangga

Rata-rata perolehan pendapatan petani dari usahatani kelapa sawit adalah Rp7.274.335,95 per hektar per tahun. Harga beras rata-rata senilai Rp15.000/kg, maka pendapatan petani dari usahatani kelapa sawit setara dengan 484,96 kg beras dalam setahun. Dengan kata lain, jika petani hanya mengandalkan pendapatan usahatani, maka rumahtangga petani termasuk dalam kategori cukup (setara 481-960 kg setara nilai beras/tahun) dalam memenuhi kebutuhan rumah tangga. Hal ini membuktikan bahwa usahatani kelapa sawit memegang peranan penting dalam meningkatkan kesejahteraan petani, mampu menyerap tenaga kerja dan meningkatkan perekonomian daerah.

Pada kondisi ini, untuk mencapai kategori hidup layak, maka harga jual TBS di tingkat petani minimal mencapai Rp1.553,40 per kg. Pada harga jual TBS senilai Rp748 per kg, maka petani harus memiliki lahan kelapa sawit minimal seluas 2,08 hektar.

\section{KESIMPULAN DAN SARAN}

\section{Kesimpulan}

Usahatani kelapa sawit

berkontribusi dalam peningkatan kesejahteraan petani. Pendapatan usahatani sebesar Rp7.274.335,95 per hektar per tahun dikategorikan cukup untuk memenuhi kebutuhan rumahtangga petani. Untuk memenuhi kategori hidup layak maka petani harus memiliki lahan minimal 2,08 hektar atau harga jual TBS di tingkat petani sebesar Rp1.553,40 per kg. Keterbatasan modal, rendahnya penerapan teknologi terutama teknologi budidaya, jarak lokasi kebun dengan tempat pemungutan hasil, jarak lokasi kebun dengan PKS, dan minimnya ketersediaan PKS akan menentukan harga jual TBS di tingkat petani.

\section{Saran}

Pengembangan usahatani kelapa sawit harus dilakukan secara maksimal terutama pada bidang budidaya dan pasca panen untuk mempertahankan kualitas dan meningkatkan harga jual TBS namun disisi lain perlu dilakukan pengembangan industri domestik berbasis kelapa sawit guna meningkatkan permintaan domestik dan mengantisipasi fenomena fluktuasi harga $\mathrm{CPO}$ di pasar internasional sekaligus meningkatkan harga TBS, pendapatan dan kesejahteraan petani kelapa sawit. 


\section{UCAPAN TERIMA KASIH}

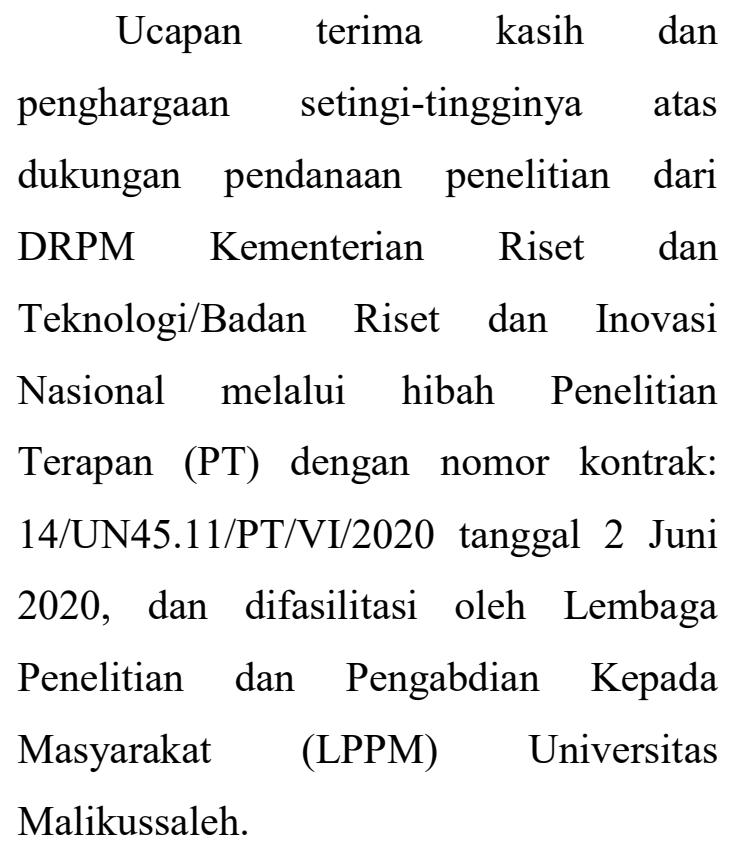

\section{DAFTAR PUSTAKA}

Alfayanti \& zul efendi. (2012). Analisis Faktor-faktor yang Mempengaruhi Produksi Kelapa Sawit Rakyat di Kabupaten Mukomuko. Jurnal Agrisep. 12(1): 1-10

Ambarsari W, Ismadi V.B., Setiadi A. (2014). Analisis pendapatan dan profitabilitas usahatani padi (Oryza sativa) di Kabupaten Indramayu. JurnalAgri Wiralodra. 6(2): 19-27

Ardana, K \& Kariyasa, K. (2016). Pengaruh inovasi teknologi dan penggunaan input terhadap produktivitas kelapa sawit di provinsi kalimantan barat. Jurnal Littri. 5(22): 125

[BPS] Badan Pusat Statistik Aceh. (2019). Aceh Dalam Angka. Badan Pusat Statistik Daerah. Banda Aceh.

[BPS] Badan Pusat Statistik Kabupaten Aceh Utara. (2019). Aceh Utara Dalam Angka. Badan Pusat Statistik Daerah. Lhoksukon, Kabupaten Aceh Utara.
Bahari, Esdwin. (2014). Analisis Strategi Peningkatan Nilai Ekonomi Sawit di Provinsi Lampung. Prosiding Seminar Bisnis \& Teknologi, 280290. Bandar Lampung. 15-16.

Efendy E, Yusuf, M.N., Jamilah, Romano, Safrida. (2014). Keragaan kelembagaan Pertanian dan Model Pengembangan Agribisnis Nilam Aceh. Jurnal Ekonomi Pertanian dan Agribisnis (JEPA). 4(4): 728737.

FAO, (2013). The plantation. FAO Corporate Document Repository. Title. Oil Palm. http://www.fao.org/docrep/006/T03 09E/T0309E03.htm.

Firdaus M \& Gunawan, I. (20.12). Integration among regional vegetable markets in Indonesia. Journal ISSAAS. 18(2): 96-106

Gumilar, P. (2018). Harga Tandan Buah Segar Anjlok Akibat Perang Dagang.

https://industri.kontan.co.id/news/p etani-sawit-minta-cabut-pungutanekspor-cpo-demi-atasi-hargarendah-tbs.

Hastuti DHD \& Rahim A. (2008). Pengantar, Teori, dan Kasus Ekonomika Pertanian. Penebar Swadaya. Jakarta.

Husni A, Hidayah K, Maskan. (2014). Analisis finansial usahatani cabai rawit(Capsicum frutescens) di Desa Purwajaya Kecamatan Loa Janan. Jurnal ARIFOR. 13(1): 49-52.

Jamilah (2010). Kajian Efisiensi Pemasaran Di Kabupaten Pidie. Jurnal Agrisep, 11(1): 9-22.

Jamilah (2014). Peluang dan Kendala Kemitraan Agribisnis Hortikultura Di Aceh. Journal Economic Manajement \& Business. 15(3): 243-252.

Jamilah, Sinaga, B.M., Tambunan M, Hakim, D.B.,(2016). Dampak Perlambatan Ekonomi China dan 


\section{KONTRIBUSI USAHATANI KELAPA SAWIT DALAM MENINGKATKAN KESEJAHTERAAN RUMAHTANGGA PETANI DI KABUPATEN ACEH UTARA \\ Jamilah, Mawardati, Ghazali Syamni}

Devaluasi Yuan Terhadap Kinerja Perdagangan Pertanian Indonesia. Jurnal Ekonomi dan keuangan (Ekuitas). 20(3): 325-345.

Jamilah, Mawardati, Syamni G. (2020). Dampak Kerjasama Perdagangan Indonesia - India dan Depresiasi Rupiah Terhadap Kinerja Ekspor Minyak Sawit Indonesia Jurnal Ekonomi Pertanian dan Agribisnis (JEPA) ISSN: 2614-4670 (p) ISSN: 2598-8174 (e) 4(3): 593-603.

Lee, J.S.H., L. Rist, K. Obidzinski, J. Ghazoul, L.P. Koh. (2011). No farmer left behind in sustainable biofuel production. Biological Conservation. 144: 2512-2516.

Lestari, Ernia E, Hutabarat S, Dewi N. (2015). Studi Komparatif Perkebunan Kelapa Sawit Rakyat Pola Plasma dan Pola Swadaya dalam Menghadapi Sertifikasi RSPO. Sorot. 10(1): 81-98.

Luntungan, A.Y., (2012). Analisis Tingkat Pendapatan Usahatani Tomat dan Apel Di Kecamatan Tompaso Kabupaten Minahasa. Jurnal Ekonomi dan Keuangan Daerah (JEKD). 7(3). 213-221

Machfud \& Rika, A.H., (2008). Model perencanaan produksi pada rantai pasok crude palm oildengan mempertimbangkan preferensi pengambil keputusan. Jurnal Teknik Industri. 10(1): 38-49.

Mawardati et al., (2021). The impact of the economic crisis on Indonesian palm oil exports: a long term simulation analysis. International eComperence on Sustainable Agriculture and Farming System. 694: 1-10.

Pahan, I. (2008). Panduan Lengkap Kelapa Sawit. Penebar Swadaya. Jakarta.
Pohan, M. (2015). Dampak Penurunan Harga Sawit Terhadap Kesejahteraan Petani Kelapa Sawit Di Pantai Timur Sumatera Utara. Jurnal Ilmu Ekonomi \& Studi Pembangunan. 15(2): 342-349.

Rist L, Feintrenie L \& Levang P. (2010). The livelihood impacts of oil palm: smallholders in Indonesia. Biodiversity and Conservation. 19: 1009-1024.

Sajogyo, T. (1997). Garis Kemiskinan dan Kebutuhan Minimum Pangan. LPSB-IPB. Bogor

Sumartono E, Ariyanti I, Sumantri B. (2018). Analisis Harga Pokok Produksi (HPP) dan Break Event Point (BEP) Produksi Crude Palm Oil (CPO) pada PT. Sandabi Indah Lestari. Jurnal Ilmu Pertanian. 30(1): 45-55.

Suratiyah, K. (2015). Ilmu Usahatan edisi revisi. Penebar Swadaya, Jakarta. 156 hal.

Waarts, Y \& Zwart, K. (2013). Investing in sustainable palm oil production: Ex-ante impact assessment of investments in a palm oil mill in Palembang, Indonesia. LEI Memorandum 13-038, May 2013. Project code 2273000166. LEI Wageningen UR, The Hague FAO. The plantation.

Wildayana, E. (2014). Formulating Oil Palm Investment Decision in Tidal Wetlands of South Sumatra, Indonesia. Indonesian Journal of Wetlands Environmental Managements (IJWEM). 2(2): 3036.

Winardi. (2004). Manajemen Perilaku Organisasi. Prenada Media. Jakarta:. 211 hal. 